\title{
ON THE IMPORTANCE OF ADVENTURE INTERPRETATION OF THE LITERARY TEXT DURING TEACHING HISTORY OF LITERATURE
}

\section{[O VYZNAME ZAZITKOVEJ INTERPRETACIE UMELECKEHO TEXTU PRI VYUCBE DEJIN LITERATURY]}

\author{
Peter Ziak - Valbona Gashi-Berisha
}

doi: 10.18355/PG.2021.10.2.4

\begin{abstract}
This study examines the phenomenon of interpretation as part of the study of the history of literature, especially in the case of teaching a foreign language. Interpretation can be about examining the immanent structures of a text, but also about reflecting the reader's relationship to the text and the way he approaches it. With regard to didactic goals, which include, in addition to professional interpretation, also a motivational factor (to teach students to like literature), we offer several innovative teaching techniques aimed at supporting adventure reading.
\end{abstract}

\section{Key words}

didactics, literature, interpretation, aesthetic experience, French language

\section{Anotácia}

Predmetom predkladanej štúdie je skúmanie interpretácie ako súčasti štúdia dejín literatúry, najmä $\mathrm{v}$ učitel'ských študijných odboroch. Pojem interpretácie je do vel'kej miery ambivalentný (na čo v príspevku poukazujeme), pretože môže označovat' tak skúmanie imanentných štruktúr (a významov) textu ako aj čitatel'skej reakcie (spôsob, akým si text čitatel' osvojuje, ako mu porozumie $\mathrm{v}$ horizonte svojej osobnej skúsenosti). Pri skúmaní významu interpetácie zohl'adňujeme aj špecifické didaktické ciele výučby dejín literatúry, medzi ktoré okrem jazykového a kultúrneho vzdelávania zarad'ujeme aj motivačnú úlohu pedagóga spočívajúcu najmä $\mathrm{v}$ tom, aby študentom priblížil estetickú stránku literatúry a $\mathrm{v}$ neposlednom rade aj jej životnú relevantnost' (Sirotová, 2010). Úlohou dobrého pedagóga literatúry je nepochybne vzbudit' v študentoch živý záujem o literatúru. Mal by ponad rámec odborného výkladu stavat' prístup $\mathrm{k}$ umeleckým textom na zážitku a potešení z čítania, ale aj na osobnej inšpirácii z vnímania optiky konkrétneho spisovatel'a. V nadväznosti na tento didaktický ciel' predkladáme niekol'ko návrhov výučby literatúry, ktoré nemajú nahradit' konvenčné metódy, ako ich skôr doplnit'. Na jednej strane môžu predstavovat' nepovinnú „nadstavbu” voči extrahovaniu kultúrne a životne relevantných informácií z textu, na druhej strane je ale ich schopnost' stimulovat' zážitkové čítanie aj najvlastnejším (a bytostne prirodzeným) prístupom k čítaniu. 


\section{Kl'účové slová}

didaktika, literatúra, interpretácia, estetický zážitok, francúzsky jazyk

\section{Vymedzenie pojmu interpretácia vzhl'adom na didaktické ciele výučby dejín literatúry}

Budúci učitelia cudzieho jazyka, ktorí $\mathrm{v}$ rámci pedagogického štúdia navštevujú prednášky a semináre zamerané na výučbu dejín a interpretácie národnej literatúry príslušnej krajiny (napríklad francúzska literatúra pre študentov francúzskeho jazyka) alebo d’alších krajín, kde v totožnom jazyku písu autori (napríklad frankofónne krajiny ako Belgicko, Kanada, Maghreb a pod.), získávajú touto cestou spoločensko-kultúrne a historické poznatky o krajine ich študijného jazyka a zároveň si osvojujú aj istú jazykovú estetiku písomnej a umelecko-slovesnej tradície. V prípade francúzskej literatúry je pre vyučujúceho jazyka a literatúry táto kultúra obzvlášt dôležitá, pretože písomná francúzština je $\mathrm{v}$ porovnaní $\mathrm{s}$ jazykom každodennej (orálnej) komunikácie značne odlišná v rovine štylistickej, lexikálnej, syntaktickej a dokonca aj gramatickej (napríklad využívanie literárneho času passé simple $\mathrm{v}$ románoch a historických spisoch). Úloha učitel’a cudzieho jazyka je v prvom rade vnímaná najmä z hl'adiska jeho schopnosti sprostredkovat' a naučit' svojich žiakov a študentov lingvistické danosti jazyka; gramatický systém a jeho využitie $\mathrm{v}$ komunikácii. Ideálny pedagóg cudzieho jazyka by však mal ako motivátor zároveň nadchnút žiakov pre samotnú kultúru či mentalitu danej krajiny - preniest' abstraktný a odt’ažitý jazykový systém, ako je prezentovaný $\mathrm{v}$ učebniciach gramatiky do jeho najvlastnejšieho kultúrneho prostredia, a najmä - ku konkrétnemu autorovi a jeho literárnemu projektu.

Myslíme si, že práve literatúra (samozrejme, spolu s d’alšími predmetmi zameranými na reálie krajiny) je najvhodnejším prostriedkom, ako vstúpit' do inej kultúry, navyše bezprostredne prostredníctvom jazyka tejto kultúry. Literárne diela nepochybne reprezentujú kultúrnu úroveň krajiny ich vzniku (a jej jazyka), avšak to, čím su umelecké naratívne texty ${ }^{1}$ výnimočné, je ich schopnost' zobrazovat' svet zo subjektívnej perspektívy postavy alebo rozprávača (schopnost' prerozprávat' dejiny svojej doby cez konkrétne životné osudy). Možno povedat', že poznávanie histórie prostredníctvom literatúry (samozrejme, pri schopnosti rozlišovat' medzi historickými a fikčnými faktmi) ,humanizuje" históriu; dodáva jej l'udský a každodenný rozmer. Táto perspektíva čítania literatúry a poznávania reálií krajiny študijného jazyka nepochybne môže zvýšit' atraktivitu výučby literatúry, najmä ak si študenti nájdu $v$ čítaných dielach okrem kolektívnych kultúrnych poznatkov aj životne (osobne) relevantné obsahy. Z hl'adiska teórie interpretácie textu vyvstáva prirodzene otázka, či osobné väzby, ktoré si čitatel' voči textu vytvára, môžu byt' súčast'ou interpretácie textu, ak ňou rozumieme interpretáciu objektívne danej významovej štruktúry.

Pojem interpretácia je, vzhl'adom na aktívnu rolu čitatel’a pri semióze textu, ambivalentný, pretože musí zahrnút okrem explicitne

\footnotetext{
${ }^{1} \mathrm{~V}$ tejto štúdii sa budeme zameriavat' $\mathrm{v}$ rámci literatúry predovšetkým na naratívne fikčné texty - teda texty s naratívnou (príbehovou) štruktúrou, ktoré odkazujú k fikčným svetom.
} 
čitatel'ných významov textu aj vel'ké množstvo nevyjadrených významov, pri ktorých text predpokladá, že ich modelový čitatel' bude dopínat' z poznatkov, ktoré v samotnom texte nie sú uvedené. Teoretici literatúry sa pochopitel'ne rozchádzajú v tom, čo je správna interpretácia, a kde sú jej hranice. Teoretické školy a koncepcie blízke tradícii formalizmu a štrukturalizmu rozumejú pod pojmom interpretácia čitatel'skú kooperácie s textom, pričom hranice interpretácie určuje samotná textúra a jej sémantická energia, ktorá musí byt' korigovaná explicitnými informáciami či implicitnými indíciami prítomnými v samotnom texte. Viac pragmatické teórie zas interpretovi textu pripisujú väčšiu mieru slobody a pripúšt’ajú, že sa interpretácia nemusí vyčerpávat' iba $\mathrm{v}$ prísnej textuálnej sémantike (close reading), ale môže obsiahnut' aj to, čo sémantická energia textu v čitatel'ovi vyvolala - či už ide o rezonovanie s „osobnostným komplexom čitatel'a” (Miko, 1970: 14) alebo $\mathrm{s}$ nejakým iným diskurzom (text $\mathrm{k}$ nemu nemusí priamo odkazovat', ale môže $\mathrm{s}$ jeho systémom výpovedí rezonovat'). Vol’ne poňatá interpretácia sa podl'a názorov stúpencov pragmatizmu leigitimizuje samotným faktom, že je prosto zaujímavejšia, podnetnejšia, užitočnejšia.

Odlišné pohl'ady na interpretáciu nemajú len čisto teoretické pozadie, ale súvisia aj $\mathrm{s}$ hodnotovými otázkami pripisovanými čítaniu a poznávaniu reality/spoločnosti prostredníctvom literárnych textov. Pokial' sa prvá skupina koncepcií javí viac normatívna či konzervatívna, druhá bude zrejme vnímaná ako viac liberálna. Vec však nesúvisí iba s tým, akú slobodu má čitatel' ,ale aj s tým, akú hodnotu pripisujeme objektívnemu poznaniu (prinajmenšom snahe o čo najväčšiu objektivitu). Literárny text posudzovaný v kontexte dejín literatúry a v kontexte štúdia cudzieho jazyka je predsa aj historickým svedectvom, prostredníctvom ktorého môžeme identifikovat' to, čo Umberto Eco nazýval „encyklopédia” (Eco, 2010: 28-29), ba čo viac znalost' príslušnej kultúrnej encyklopédie determinuje aj čitatel'ské porozumenie textu. Nemáme pritom na mysli redukcionistickú tézu o literatúre ako prostom odraze vonkajšej reality, ale fakt, že literatúra čerpá reálie, vzt’ahy, pomery a názory zo svojho sociálneho prostredia, pričom ich zároveň modifikuje a dáva do nového kontextu. Spisovatelia hladajú formu svojho písania aj pod tlakom svojho súdobého prostredia a jeho špecifických problémov.

Frédéric Tellier $\mathrm{v}$ brilantnej eseji La société et son double (Spoločnost' a jej dvojník) tvrdí, že spracovanie spoločenskej látky do literárnej formy (týka sa to najmä naratívnych textov) predstavuje pre spoločnost' vyšší stupeň kolektívneho sebapoznania a sebareflexie. Nie je to teda tak, že by literatúra bola odrazom reality, ale je skôr sémanticky zhutneným symbolickým modelom sveta (aj ked’ sveta fikčného): „Na spoločenskú realitu sa pozeráme z dvoch perspektív. Na jednej strane sa nechávame unášat' detailmi našich konkrétnych životov; neustálymi výkyvmi l'udských atómov. Okrem toho však máme schopnost' vnímat' svet aj z väčšej perspektívy - poetickej - , ktorá zachytáva to, čo sa opakuje a ktorá hl'adá v nejakej jednotiacej forme zmysel platný pre každého zúčastneného. Táto forma predstavuje akýsi pevný bod našej zdiel'anej intencionality" (Tellier, 2003: 59). Príkladom môžu byt' Balzacove romány: v epoche vel'kej 
transformácie spoločnosti na trhový kapitalizmus zachytili spoločenské mechanizmy, ktoré by sa bez výraznej typizácie (preexponovaného výskytu istého typu vlastností pri postave ale aj prostredí alebo deji) v žánri realistického románu nedostali do spoločenského povedomia (najmä d’alších generácií čitatel'ov) $\mathrm{v}$ tak frapantnej podobe. Pritom Balzac typizačným postupm evidentne transformuje spoločenskú látku vzhl’adom na ontologickú pravdepodobnost' posudzovanú $\mathrm{z}$ hl'adiska reálneho sveta (k Blazacovej typizácii pozri viac v Povchanič, 2011: 61-62).

Literárne texty modelujú $\mathrm{v}$ porovnaní $\mathrm{s}$ naším každodenným prežívaním reality ovel'a hutnejšiu a systematickejšiu sémantickú štruktúru (k tomu pozri aj Lotman, 1990: 22-23). Aj preto má zmysel čítat' ich s dôrazom na významový plán, ktorý nám umožňuje porozumiet' príslušnému historickému obdobiu a kultúre, ako aj formálnym postupom najlepšie vystihujúcim spoločenské pomery ${ }^{2}$. Práve cez úspešnú kooperáciu $\mathrm{s}$ textovými stratégiami môže čitatel' dospiet' $\mathrm{k}$ híbkovým - aktančným a ideologickým - štruktúram textu (k tomu pozri Greimas, 2002: 181; Eco, 2010: 209), ktoré obohacujú naratívy o spoločensky ale aj životne relevantné významy.

\section{Interpretácia}

Predstava, že čitatel' sa má správat' $\mathrm{v}$ texte disciplinovane, vyvoláva nepochybne pocit obmedzovania pôžitku z hry čítania, avšak vzhl'adom na noeticky orientovanú interpretáciu prináša takáto recepcia väčšie obohatenie.

Nie je napokon všeobecne platné, že by disciplinované čítanie automaticky viedlo $\mathrm{k}$ menej intenzívnemu zážitku. Autorita textu, ktorá sa prejavuje v limitoch vnucujúcich textu interpretačné limity, môže predstavovat' pre čitatel'a nové podnety či povestné ozvláštnenie - zmenu vo vzt'ahu ku každodennosti, $\mathrm{k}$ zaužívaným výkladovým postupom či $\mathrm{k}$ názorom a hodnotám čitatel'a.

Je nepochybné, že každý čitatel' potrebuje k úspešnej interpretácii použit' kultúrnu encyklopédiu (Eco) či skúsenostný komplex (Miko), teda kultúrne a životné znalosti, skúsenosti a poznávacie schémy. V tomto zmysle sú významy textu skutočne závislé na ovel’a širšom mimotextovom kontexte, pretože „parazitujú” na istých znalostiach a predpokladoch, ktorými má modelový čitatel' disponovat', aby mohol dekódovat' napríklad implicitné významy (to sa týka aj híbkových štruktúr textu) a doplńnat' takzvané gapy (významové medzery $\mathrm{v}$ texte). Naratívy dokonca budujú aj napätie, zvedavost', očakávania a prekvapenia na istých zaužívaných scenároch (frames) a predpokladajú, že čitatel' sa nimi bude riadit' (to platí mimochodom aj pre $\mathrm{v}$ súčasnosti vel'mi populárny žáner televíznych či streamovaných seriálov). Napätie, zvedavost' a prekvapenie pritom patria $\mathrm{k}$ afektívnym reakciám čitatel’a a ako také bývajú zdrojom najsilnejších estetických zážitkov (k tomu pozri Baroni, 2007: 40-41).

\footnotetext{
${ }^{2}$ Dvaja klúčoví teoretici románu, György Lukács a Michail M. Bachtin (hoci sú ich koncepcie v mnohom protikladné), sa zhodujú napríklad $\mathrm{v}$ tom, že román ako žáner najlepšie vystihuje problémový charakter moderného sveta čo do možnosti symbolcikého zjednotenia (pozri Lukács, 2012: 49; Bachtin, 1973: 67).
} 
Literárne texty možno systematicky skúmat' na viacerých „poschodiach” - od roviny jazykovej cez kultúrny kód (encyklopédia), naratívne postupy, až po základné konflikty a ich hodnotové implikácie. Umberto Eco pokladal práve tieto úrovne textu za hlavné sémantické plány, $\mathrm{v}$ ktorých sa rozohrávajú textové stratégie (a s ktorými by mal čitatel' úspešne kooperovat'). Nejde pritom o zákonite sukcesívny proces, pretože čitatel' už na začiatku recepcie predpokladá, že príbeh bude mat' ústrednú tému a že sa $\mathrm{v}$ rámci nej bude zobrazovat' základný konflikt a hodnotové problémy ${ }^{3}$, taktiež že sa príbeh bude vyvíjat' $\mathrm{v}$ rámci istých pravdepodobných naratívnych postupov. Eco k tomu dodáva: „Čtenář si tak na jedné straně už musel vytvořit domněnku o roli postavy $\mathrm{v}$ daném úseku textu, aby mohl formulovat své narativní makrokompozice, a na strané druhé už musel rozpoznat stavy fabule $\mathrm{v}$ jejich logické následnosti, aby mohl určit, zdali daný úsek textu reprezentuje fakt, který se právě děje, který se stal, na který se vzpomíná, $\mathrm{v}$ nějž se $\mathrm{v}$ minulosti věřilo a pak byl následnou realitou vyvrácen atd." (Eco, 2010: 210). Predvídanie a následné overovanie sa týka aj tak implicitných vrstiev, akými sú aktančné schémy (hĺbkové opozície): „Víme, aspoň po provedené kritické rekonstrukci, že text má, nebo by měl mít tu či onu aktanční strukturu, stěží bychom však mohli říci, ve které fázi kooperace je Modelový Čtenář vyzván, aby ji identifikoval” (Ibid.: 212).

$\mathrm{V}$ nedávno publikovanej monografii Estetika naratívnych textov (Žiak, 2021) sme skúmali, ako literárne postupy naratívnych textov ovplyvňujú vznik a priebeh estetického zážitku. Osobitý dôraz sme kládli na vzt’ah medzi záujmom o tému a pútavým rozprávaním, ktoré okrem sledovania zápletky implikuje aj potešenie z rekonštrukcie fikčného sveta a pôžitok z imaginárnej prítomnosti $\mathrm{v}$ n̆om (popri postavách, ich krajinách a situáciách, ktorým čelia). Identifikovali sme napríklad zaujímavé spojitosti medzi naratologickou koncepciou Raphaëla Baroniho a teóriou estetického zážitku Františka Mika (ústrednej postavy „,nitrianskej školy”) ${ }^{4}$. Obaja autori určujú napätie ako základný podnet záujmu čitatel'a o zotrvanie v recepcii, avšak pokial' Miko situuje tento záujem do tematického či existenciálneho plánu diela, Baroni ho nachádza najmä $\mathrm{v}$ naratívnych postupoch, čím rozširuje pôsobenie tenzie a detenzie aj na zážitok z priebehu rozprávania.

Ako sme uvedené koncepcie porovnávali (a interpretačne aplikovali na konkrétne naratívy), dospeli sme k záveru, že naratívny a hermeneutický záujem (potešenie z vývoja zápletky a objavovania sveta na jednej strane a

\footnotetext{
${ }^{3}$ Podl'a Jonathana Cullera patrí k základným čitatel’ským kompetenciám aj predpoklad, že literárny naratív bude komunikovat' dôležitú tému (pozri Culler, 2001: 134).

${ }^{4}$ Baroni vo svojej knihe La tension narrative (Naratívne napätie) skúma naratívne štruktúry z hl'adiska ich schopnosti podnecovat' čitatel'a, aby v recepcii zotrval a mal z nej pôžitok. Deje sa to predovšetkým stupňovaním naratívneho napätia (pozri Baroni, 2007: 49). František Miko zas tvrdí, že literárny text sa stáva estetický účinným či prít’ažlivým vtedy, ked' sa jeho ústrednou témou stáva konflikt (napätie) a snaha o jeho prekonanie (uvol’nenie napätia). Tenzívnodetenzívne pulzovanie narácie, prostredníctvom ktorého sa životné problémy postáv rozkrývajú, sa stáva podl'a Mika hlavným zdrojom zážitku: „Estetická miera riešenia l'udského životného problému je v rozhodujúcej miere zodpovedná za estetickú povahu informácie, ktorú nesie v sebe umelecké dielo. V nej sa zakladá estetická hodnota diela” (Miko, 1978: 60).
} 
záujem o tematickú rovinu príbehu na druhej strane) sa môžu navzájom umocňovat' a predstavujú rovnocenné zložky, nakol'ko nikdy nevieme, ktorá $\mathrm{z}$ nich bude $\mathrm{k}$ konkrétnej recepcii zdrojom estetického potešenia: „Z uvedeného vyplýva, že nemožno jednoznančne a univerzalisticky tvrdit', čo je v texte zdrojom estetického zážitku. Spustenie estetického postoja závisí na tých aspektoch textu, ktoré udržiavajú čitatel'ov záujem o zotrvanie v recepcii a poskytujú zároveň potešenie z recepcie samotnej” (Žiak, 2021: 136). Vynáranie estetických kvalít, ktoré aktivujú v recipientovi estetický režim vnímania, súvisí s účinkom ozvláštnenia (na princípe figúra - pozadie), ktoré sa neredukuje len na literárno-štylistické a kompozičné postupy (ako sa domnievali ruskí formalisti ${ }^{5}$ ), ale prejavuje sa aj v širšom rámci recepčného naladenia čitatel'a: „Ozvláštnenie môže byt' pocit'ované nielen pri špecifikcej organizácii jazykového materiálu (básnické prostriedky, kompozícia), ale aj na úrovni témy a zápletky (striedanie tenzívnych a detenzívnych zložiek, kontrast, konflikty). Ozvláštnenie môže mat' intertextuálne pozadie (neobvyklý príbeh, neobvyklá práca so žánrovými konvenciami, scenármi) a môže fungovat' napokon aj vo vzt'ahu k extratextovej realite (kontrast medzi realitou príbehu a životnou realitou recipienta). Nemožno teda povedat', či u konkrétneho recipienta bude zdrojom estetického zážitku špecifický jazyk, naratívne postupy alebo zobrazená životná situácia” (Ibid.: 137). Videoherným slovníkom možno povedat', že zdrojom estetickej pôsobnosti môže byt' tak playing (pôžitok z hrania, t.j. z čítania) ako aj game (záujem o problémy a konflikty, ktoré hra predkladá).

Ideálna čitatel'ská kooperácia $\mathrm{s}$ textom nastane nepochybne $\mathrm{v}$ prípade, ked' sa prepojí intelektuálne porozumenie s pútavým zážitkom takým spôsobom, aby čitatel' bytostne prežil príbeh do takej miery, že prenikne aj do oblasti jeho hodnotovo-názorových a životne-motivačných orientácií. Vel'ké umelecké diela nepochybne majú túto silu a právom reprezentujú výnimočnú schopnost' literatúry sugestívne popísat' život v jeho rozmanitých chutiach, intenzívnych zážitkoch, ale aj drámach, pádoch a úbohosti. Ako hovorí Terry Eagleton, literatúra ,zobrazuje život ve vší jeho bohaté rozmanitosti a namísto neplodného konceptuálního doumáni chce zakusit a pocítit, jaké to je být naživu" (Eagleton, 2010: 231).

Záujem o literatúru, ktorý musí prebudit' pedagóg vo svojich žiakoch, sa nemsie vyčerpávat' $\mathrm{v}$ inštrumentálnom prístupe $\mathrm{k}$ literatúre ako prostriedku šírenia národnej identity, bohatosti jazyka, l'udských hodnôt či estetických noriem (Michvocíková, 2019). Estetický záujem musí byt' podnecovaný hlavne cez životnú konkrétnost', ktorou literatúra prehovára $\mathrm{k}$ čitatel'ovi najintímnejšie. Na druhej strane však formálny rozbor textu ako komplexnej naratívnej štruktúry vytvárajúcej príbeh prehlbuje estetický cit pre vnímanie poetiky písania, ktorú spoluutvára jazyk, štýl, téma a naratívne postupy. Čitatel', ktorý prehlbuje svoju schopnost' vnímat' okrem účinku textu aj stratégie, ktoré ho spôsobujú, lepšie porozumie aj literárnym tvorivým postupom, ktoré môže využit' nielen pri d'alšej recepcii, ale aj pri prípadnej vlastnej tvorbe. Tieto čitatel'ské schopnosti sú vel'mi užitočné napríklad pre

\footnotetext{
${ }^{5}$ K tomu pozri Šklovskij, 1971: 24, 33.
} 
prekladatel'ov umeleckých textov, ktorí musia porozumiet' tomu, akými prostriedkami autori vytvorili konkrétne výrazové kvality, a potom tieto prostriedky $\mathrm{v}$ rámci tvorby prekladového textu prehodnotit'.

$\mathrm{V}$ nasledujúcej kapitole sa zmienime o niektorých inovatívnych postupoch, pri ktorých by mohli študenti uplatnit’ naratologické znalosti a zážitkové čítanie zároveň. Tieto metódy možno označot' ako pragmatické použitie textu, avšak nemusí íst' nutne o čitatel'skú pod/nadinterpretáciu (ked' je čitatel' schopný rozlišovat' medzi interpretáciou ako rekonštruovaním zámeru textu a interpretáciou ako vol'ným ale zmysluplným použitím textu).

\section{Aplikácia zážitkovej interpretácie na hodinách francúzskej literatúry}

$\mathrm{Na}$ hodnách francúzskej prózy 20. storočia sme venovali výnimočnú pozornost' románu Marcela Prousta Hladanie strateného času. Z pozície vyučujúceho sme otvorene priznali osobný vzt’ah $\mathrm{k}$ románu, čo sme považovali za pozitívnu motiváciu (demonštrovat', že literatúra má schopnost' životne nás ovplyvnit'). Okrem toho však Proustov román obsahuje vel'mi rozvinuté modernistické naratívne postupy, ktoré rozprávačovi umožňujú prerozprávat' príbeh jedného života $\mathrm{v}$ neustále sa prelínajúcich a unikajúcich časových percepciách. Tak ako Proustov rozprávač z jednej spomienky vyvolanej chut'ou koláčika madeleine opätovne objavoval svoje detstvo $\mathrm{v}$ spomienke a potom sa navracal spät' k spisovatel'ovi, ktorým sa na začiatku románu ešte len mal stat', zobrazil zároveň aj zánik starého sveta artistokracie - moci a pátosu vel'kých rodov na prelome storočí. Parafrázujúc Waltera Benjamina môžeme povedat', že Proust vo svojom románe dokázal okolo jedného života nechat' zostarnút' jeden svet (Benjamin, 2009: 245).

Dej ako dominantná zložka epiky sa v Proustovom románe st’ahuje do vnútra postavy. Naratívne postupy, pomocou ktorých Marcel (postava a rozprávač $\mathrm{v}$ jednej osobe) vybudoval vnútorne psychologizované vnímanie spoločnosti, má v sebe silný atraktivizačný potenciál. Narátor reflektuje svoju dobu s vel'mi rozvinutým estetickým ale aj analyticko-syntetickým pohl'adom, nakol'ko ide o vel'mi prenikavého pozorovatel'a s čoraz silnejšou potrebou pretavit' celú životnú skúsenost' do písania. Známa je jeho veta $\mathrm{z}$ posledného dielu románu (Čas znovu nájdený) - citujme z českého prekladu: „Pravý život konečně odhalený a osvětlený, a tudiž jediný život reálně proživaný, tot' právě literatura; ten život, který tak jako existuje u umělce, existuje v jistém smyslu v kterémkoli okamžiku u všech lidi" (Proust, 2012: 207 - VII. diel).

So študentmi sme analyzovali niekol'ko textových pasáží, v ktorých Proust vel'mi sugestívne prepájal opis vonkajšieho sveta a spôsob, ako sa v jeho vedomí vynáral a zafarboval osobnými dojmami. Uved'me aspoň stručný citát z jednej takejto pasáže: „Květiny, které si tenkrát hrávaly v trávě, voda plynoucí na slunci, celá ta krajina, která tvořila pozadí jejich objevení, i nadále provázejí svou nevédomou nebo roztržitou tvář́i vzpomínku na ně; a tehdy, když je dlouho pozoroval ten skromný chodec, to zasněné ditě (...), jistě by si onen kout prírody, onen kousek zahrady nepomyslely, že diky nému budou povolány $k$ tomu, aby prežili právě ve svých nejpomíjivějšich zvláštnostech (...), mé vytrženi to všechno odneslo s sebou a bylo s to uchovat 
to po tak dlouhou radu let, zatímco okolní cesty zarostly, a ti, kdo po nich chodili, zemřeli a zemřela i jejich památka" (Proust, 2012: 166-167 - I. diel) ${ }^{6}$.

Pri spätnom pohl'ade na hodiny venované Proustovi uvažujeme nad tým, či nebolo na škodu nepostavit' na podobných naratívnych postupoch (ktoré sme na hodinách iba analyzovali a interpretovali) aj cvičenia zamerané na tvorivé písanie. Osvojené štandardy vo vysokoškolskej výučbe nás zrejme od podobných aktivít skôr vzdial'ovali, avšak práve pokus o uplatnenie Proustovho vnímania reality by nepochybne študentom poskytol sugestívnejší zážitkový vhl'ad do istej autorskej perspektívy a literárnej poetiky zároveň. Nepochyne by si študenti Prousta lepšie zapamätali, najmä ak by im takáto skúsenost' umožnila porozumiet' tomu, že literárne diela nás môžu v živote ovplyvňovat" ${ }^{7}$. Ak by sme doplnili komplexnú interpretáciu textu (vzt'ah témy a spôsobu jej naratívneho spracovania) o uplatnenie obdobnej rozprávačskej perspektívy v cvičeniach zameraných na opis svojich vlastných dojmov zo života a spoločnosti, nepochybne by sme prehĺbili našu schopnost' „vcítit” sa do Prousta a z literárno-estetického hl'adiska aj schopnost' porozumiet' tomu, ako pomocou literárnych postupov možno vyvolat' špecifický typ zážitku. Vedomosti na tejto úrovni presahujú deduktívne poznatky osvojené $\mathrm{v}$ schematickej výuke smerom k hlbšiemu prozoumeniu (či dokonca precíteniu) estetických vlastností textu. Pritom zážitkové čítanie Prousta môže byt' funkčne prepojené s výkladom nielen literárneho modernizmu a naratívnych postupov vo všeobecnosti, ale aj typicky francúzskej intelektuálnej zál'uby diskutovat' o vel'kých témach $\mathrm{s}$ precíznou detialnost'ou; až manieristicky (či estétsky). Tento obl'úbený postup spája spisovatel'ov a filozofov a je typickou súčast'ou mentálneho sveta francúzskej inteligencie. Finesa je napokon už celé stáročia kultúrnycm exportom Francúzska a nie je dôvod, prečo by ju nemali študenti francúzskej literatúry spoznávat' - najmä ak sa uplatňuje v jazyku a literatúre.

Ak by sa niekomu zapojenie tvorivého písania zdalo príliš vzdialené ciel'om výučby dejín literatúry, vel'mi vhodným (a snád' aj akademicky celkom prijatel'ným) postupom môže byt' tvorivá interpretácia (pozri Hník, 2014: 61), v rámci ktorej môžu študenti otvorene hovorit’ o svojom vzt'ahu $\mathrm{k}$ textu a o dojme $\mathrm{z}$ čítania (podobné otázky sme kládli študentom pri prezentácii svojich referátov), dokonca aj uvažovat' o tom, aký čitatel'ský výklad a kontext môžu dielo urobit' interpretačne zaujímavým, aj ked' k tomu kontextu v samotnom diele nie sú prítomné odkazy. V tomto prípade možno hovorit' o typicky pragmatickej interpretácii. Jej užitočnost' sa môže prejavovat' nielen vo vzt'ahu $\mathrm{k}$ čitatel'ovi, ale aj vo vzt'ahu $\mathrm{k}$ literatúre ako živej kultúre.

\footnotetext{
${ }^{6}$ Dodajme, že podobné opisy tematizujú nielen prírodu ale aj spoločenské udalosti, ktoré evokujú mnoho skutočných udalostí z dejín vtedajšieho Francúzska.

${ }^{7}$ Niekol'ko vel'mi zaujímavých životných lekcií z Prousta ponúka vo svojej eseji Ako môže Proust zmenit' váš život Alain de Botton (2010). Autor sa drží prístupu protichodného projektívnemu čítaniu - neskúma to, čo môžeme v Proustovi nájst' blízke nášmu životu, ale to, ako môžeme zmenit' optiku vnímania aplikovaním tej spisovatel'ovej.
} 
Aj historicky alebo kultúrne vzdialené texty môžu týmto spôsobom prehovárat' $\mathrm{k}$ súčasnému čitatel'ovi ako „nové” perspektívy vnímania súčasného života (naučit' sa pozerat' na svet očami spisovatel'a). Potom sa aj pod/nadinterpretácia, ktorá interpretačne „,používa” text inak, ako sám chce (intencia textu), môže stat' prínosnou súčast'ou literárneho a širšieho kultúrneho vzdelávania. Sami sme na kurze francúzskeho románu 19. storočia uplatnili tento prístup a určili ako tému semestrálnej práce analýzu vzt’ahu románu Naruby (Joris-Karl Huysmans) a románu Podvolenie (Michel Houellebecq). Hlavnou postavou románu Michela Houellebecqa (jedného z najčítanejších francúzskych spisovatel'ov dneška) je literárny vedec a univerzitný profesor, ktorý sa špecializuje na Huysmansovo dielo (autora $\mathrm{z}$ konca 19. storočia, ktorý sa v románe Naruby rozišiel so zolovskou poetikou všedného života a svojím estétstvom kombinovaným s mizantropiou vyjadril nezáujem o spoločnost' ako takú). François - ako aj d'alší protagonisti Houellebecqových románov - zaujíma voči svetu približne rovnaký postoj ako Huysmansov (anti)hrdina, avšak protagonista románu zo súčasnosti žije v inej sociálnej realite. Bolo zaujímavé sledovat', ako študenti nachádzali podobnosti a rozdiely nielen medzi dvoma dielami, ale aj medzi dvoma epochami a zároveň reflektovali niektoré naliehavé problémy súčasnej spoločnosti. (Je pravda, že tieto významy boli evokované V Houellebecqovom románe, avšak aj bez toho by bola takáto komparácia $\mathrm{v}$ mnohom obohacujúca a interpretačne podnetná.)

\section{Záver}

Vyučovanie literatúry na univerzitnej pôde musí dosahovat' istú úroveň a odbornost'. Neštandardné metódy nemôžu úplne vytlačit' prednáškovú výučbu a tvorivé aktivity nemôžu nahradit' vedeckú analýzu textu (Šeben Zat'ková, 2015). Nesmieme však zabúdat', že umelecká literatúra je najmä estetický fenomén a jej zážitkové čítanie iba napĺn̆a intenciu textu, preto by mal učitel' literatúry podnecovat' vo svojich študentoch aj osobný prístup k literatúre a navrhovat' čítanie, ktoré neprináša len relevantné informácie o istej kultúre, ale aj estetický pôžitok. Ak je to $\mathrm{v}$ rámci stanovených osnov literárno-historických a literárno-interpretačných predmetov možné, vyučujúci by mal podl'a nášho názoru vždy uprednostňovat' kvalitu nad kvantitou a v súlade s tým zvážit' aj väčšiu redukciu učiva vyváženú hĺbkovou interpretáciou niekol'kých významných autorov, ich poetík a najmä konkrétnych diel (takí autori môžu byt' vyberaní aj vzhl'adom na mieru inovatívnosti a vplyvu na d'alších autorov a v tomto zmysle byt' pokladaní za reprezentatívny príklad univerzálnejších tendencií).

Sme presvedčení, že iba v intímnom styku s textom možno pochopit' raison d'être literatúry ako umeleckej tvorby. Jej zážitkový potenciál sa v školskom vzdelávaní často prehliada $\mathrm{v}$ prospech reprezentatívnej funkcie (literatúra ako prejav vel'kosti národa, národného jazyka) a vyučujúci, ktorí nedemonštrujú na vyučovaní osobný zážitok z čítania, iba vel'mi t’ažko vytvoria vo svojich študentoch vnútornú motiváciu čítat' (ani motivácia založená na vôli poznat' kultúru jazyka, ktorý sa učia, nepredstavuje ešte 
osobný vzt'ah k literatúre, pretože nesmeruje k porozumeniu jej jedinečnosti v porovnaní s historickými textami, esejami, štúdiami a pod.).

Vyššie navrhované vyučovacie metódy majú väčší potenciál aktivovat emocionálne ale aj osobné - motivačné a hodnotové - zložky osobnosti, ktoré sa pri čítaní zameranom na objektívne štruktúry textu nemusia do takej miery zapájat', ba môžu ostat' aj úplne nereflektované či zamlčané (napríklad ked' sa vyučujúci nezaujíma o osobný dojem z čítania a názory študentov na dielo). Naša osobná skúsenost' nás poučila, že deduktívny prístup $\mathrm{k}$ dielu spočívajúce $\mathrm{v}$ interpretačných rámcoch určených vyučujúcim ako garantom odbornosti a „správneho" čítania, neprehlbuje v študentoch hlbšie porozumenie literatúry - ostáva takpovediac „školácke”, poučkovité. Až osobný zážitok a osobné porozumenie diela a jeho následná interpretácia (najlepšie aj vo formálnom rámci semestrálnej práce) majú skutočný prínos pre študenta literatúry a veríme, že iba toto spojenie prirodzeného a spontánneho (čítanie pre potešenie) na jednej strane a intelektuálne a odborne náročného (literárnovedná analýza textu) na druhej strane skutočne prehlbuje čitatel'ove literárne kompetencie a vlastne aj jeho osobnost'.

\section{Bibliographic references}

BACHTIN, M. M. 1973. Problemy poetiky romanu. Bratislava: Slovensky spisovatel.

BARONI, R. 2007. La tension narrative: Suspence, curiosite et surprise. Paris: Editions du Seuil. ISBN 978-2-02-090677-7

BENJAMIN, W. 2009. K Proustovu obrazu. In: Vybor $\mathrm{z}$ dila I: Literarnevedne studie. Praha: OIKOYMENH. ISBN 978-80-7298-278-3

BOTTON, A. de. 2010. Comment Proust peut changer votre vie. Paris: Editions Flammarion. ISBN 978-2-290-02804-9

CULLER, J. 2001. Structuralist Poetics: Structuralism, linguistics and the study of literature. London and New York: Routledge. ISBN 978-0-41528989-4

EAGLETON, T. 2010. Uvod do literarni teorie. Praha: Plus. ISBN 978-8000-02587-2

ECO, U. 2010. Lector in fabula: Role ctenare aneb Interpretacni kooperace v narativnich textech. Praha: Academia. ISBN 978-80-200-1828-1

GREIMAS, A. J. 2002. Semantique structurale: Recherche de methode. Paris: Presses Universitaires de France. ISBN 978-2-13-052763-3

HNIK. O. 2014. Didaktika literatury: vyzvy oboru. Od textu umelecke povahy k didaktice estetickovychovneho oboru. Praha: Univerzita Karlova v Praze. ISBN 978-80-246-2626-0

LOTMAN, J. M. 1990. Struktura umeleckeho textu. Bratislava: Tatran. ISBN 80-222-0188-X

LUKACS. G. 2012. La theorie du roman. Paris: Editions Denoel. ISBN 9782-07-071219-9

MICHVOCIKOVA, V. 2019. Formovanie narodnej ideologie v edukacnom procese vysokych skol. Nadlak: Editura Ivan Krasko. ISBN 978-973-107$144-2$ 
MIKO, F. 1970. Text a styl. K problematike literarnej komunikacie. Bratislava: Smena. Bez ISBN

MIKO. F. 1978. Esteticka komunikacia. In: Miko, F. - Popovic, A. 1978. Tvorba a recepcia: Esteticka komunikacia a metakomunikacia. Bratislava: Tatran Bez ISBN.

POVCHANIC. S. 2011. Dynamika literarnych sytemov: Vyvinove tendencie francuzskej literatury v 19. storoci. Bratislava: Ekonom. ISBN 978-80-2253210-5

PROUST, M. 2012. Hledani ztraceneho casu I: Svet Swannovych. Praha: Rybka Publishers. ISBN 978-80-87067-63-5

PROUST, M. 2012. Hledani ztraceneho casu VII: Cas znovu nalezeny. ISBN 978-80-87067-63-5

SIROTOVA, M. 2010. Vyucovacie metody v praci vysokoskolskeho ucitela. Trnava: UCM. ISBN 978-80-810-5201-9

SEBEN ZATKOVA, T. 2015. Vybrane kapitoly z vysokoskolskej pedagogiky. Nitra: SPU. ISBN 978-80-552-1431-3

SKLOVSKIJ. V. 1971. Teoria prozy. Bratislava: Tatran. Bez ISBN

TELLIER F. 2003. La societe et son double: Essai sur les formes sociales.

Paris: Editions Climats. ISBN 978-2-841-58224-2

ZIAK, P. 2021. Estetika narativnych textov. Nitra: Univerzita Konstantina Filozofa v Nitre. ISBN 978-80-558-1714-9

PhDr. Peter Žiak, PhD.

Gymnázium. sv. Uršule

Nedbalova 4

81101 Bratislava

Slovakia

pepeziak@gmail.com

Prof. Valbona Gashi-Berisha

University "Hasan Prishtina" of Prishtina,

Rr "George Bush", p.n.,

10000 Prishtina,

Republic of Kosovo

valbonagashi@uni-pr.edu 